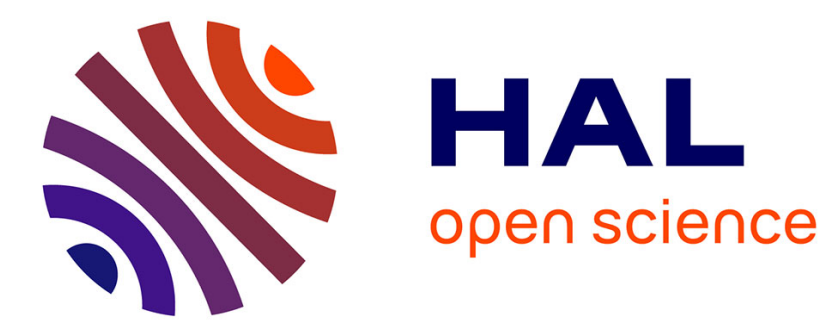

\title{
Vulnerabilities in Central and Eastern Europe: Credit Growth
}

\author{
Aleksandra Zdzienicka-Durand
}

\section{To cite this version:}

Aleksandra Zdzienicka-Durand. Vulnerabilities in Central and Eastern Europe: Credit Growth. 2009. halshs-00384566

\section{HAL Id: halshs-00384566 \\ https://shs.hal.science/halshs-00384566}

Submitted on 15 May 2009

HAL is a multi-disciplinary open access archive for the deposit and dissemination of scientific research documents, whether they are published or not. The documents may come from teaching and research institutions in France or abroad, or from public or private research centers.
L'archive ouverte pluridisciplinaire HAL, est destinée au dépôt et à la diffusion de documents scientifiques de niveau recherche, publiés ou non, émanant des établissements d'enseignement et de recherche français ou étrangers, des laboratoires publics ou privés. 


\title{
Vulnerabilities in Central and Eastern Europe : Credit Growth
}

\author{
Aleksandra Zdzienicka
}

Mai 2009

GATE Groupe d'Analyse et de Théorie Économique UMR 5824 du CNRS

93 chemin des Mouilles - 69130 Écully - France

B.P. 167 - 69131 Écully Cedex

Tél. +33 (0)4 72866060 - Fax +33 (0)4 72866090

Messagerie électronique gate@gate.cnrs.fr

Serveur Web : www.gate.cnrs.fr 


\title{
Vulnerabilities in CENTRAL AND EASTERN EUROPE: CREDIT GROWTH
}

\author{
Aleksandra ZDZIENICKA ${ }^{1}$
}

December, 2008

\begin{abstract}
In this work, we try to analyze the recent credit development in 11 Central and Eastern European countries and estimate the credit-to-GDP ratio equilibrium level using filtering methods and dynamic panel estimations. Our estimation findings corroborate previous fears about the rapid credit growth in the CEECs. Indeed, in many cases the credit expansion exceeds the level justified by their fundamentals or financial development.

Under normal conditions, this rapid growth and even "overshooting" of banking credit could be considered as an adjustment to its long-term equilibrium level. However, in the actual crisis situation, this excessive credit growth can reinforce other existing disequilibria and lead to an increase in the financial vulnerability of these countries.
\end{abstract}

JEL classification: $\mathrm{C} 2, \mathrm{G} 21$

Keywords: Bank Credit Growth, Dynamic Panel, CEECs

${ }^{1}$ GATE-CNRS/ENS LSH, University of Lyon, email: azdzieni@ens-lsh.fr 


\section{Introduction}

There exists a general agreement among economists that strong credit growth has been "one of the most pervasive developments" (Enoch, 2007) in most of Central and Eastern European countries (CEECs hereafter) in the recent years. Indeed, the average annual real growth bank credit to the private sector has reached over 20 per cent during the last seven years (Table 1). This development seems even more important when compared with other regions of the world where cumulative credit growth has been small or even negative over the same period. However, these figures capture only part of an ongoing phenomenon and credit expansion has been certainly greater when considering the growing importance of nonbank financial institutions in the CEECs.

The development of credit growth in this region remains, however, relatively uncertain. On the one hand the ongoing world financial crisis will most probably slow down credit growth and even lead to "credit crunch" in some countries. On the other hand, dynamic credit growth can accelerate again with progress in the CEECs' economic and monetary integration. In any case, even if greater credit dynamics bring unquestionable benefits for financial and economic development, their potential risks cannot be ignored. Indeed, negative repercussions of "excessive" credit growth, such as consumption and investment booms leading to economic overheating, greater external disequilibria, banking and currency crises, are widely known and feared. This is why the credit development in the CEECs, showing in many aspects these negative features, has constituted a matter of growing concern.

The main objective of this paper is to shed some light on the recent credit development in a group of 11 CEEC countries, analyzing whether the credit increase could be considered as "excessive". 
This assessment is rather difficult to perform especially in the case of the transition economies where excess of credit with respect to long-term equilibrium can be considered as part of the adjustment process. Thus, to better tackle the credit growth problem in the new countries we follow a two-step approach. First, we try to determine the "excessiveness" of credit growth when comparing to the CEECs' financial development and previous leading-to-crises experiences. Then, we estimate the credit deviation from its long-term determined-byfundaments equilibrium, where to avoid the bias of the CEECs' adjustment process we estimate the equilibrium level for developed European countries, which can be considered their "natural" benchmark.

The estimation results based on filtering methods, and static and dynamic panel techniques confirm significant acceleration in credit growth for almost all countries taken in exam. In particular, in most of them, the credit growth significantly exceeds the level which is consistent with financial development and macroeconomic fundamentals since at least 2006 . These findings corroborate the thesis about credit "overshooting" in its adjustment to the longrun equilibrium putted forward by some authors (Backé et al., 2006), and the fact that this rapid credit growth coupled with other important disequilibria (e.g. external debt, currency mismatch) has considerably increased financial risks in these countries.

The rest of the paper is organized as follows. Section 2 briefly describes stylized facts about the CEECs' financial and banking sectors. Section 3 provides theoretical and empirical explanations of credit growth. Section 4 presents methodological issues. Section 5 reports the results. Finally, Section 6 concludes. 
Table 1: Bank Credit to the Private Sector, \% Growth in Real Terms*, over the 2000-2007 period

\begin{tabular}{|c|c|c|c|c|c|c|c|c|c|}
\hline Credit Growth & 2000 & 2001 & 2002 & 2003 & 2004 & 2005 & 2006 & 2007 & Average \\
\hline Bulgaria & 6,0 & 23,1 & 34,6 & 45,7 & 40,1 & 26,2 & 16,3 & 50,0 & 30,3 \\
Croatia & 2,9 & 18,4 & 28,3 & 13,1 & 12,2 & 13,1 & 19,1 & n.a. & $15,3 * *$ \\
Czech Rep. & $-9,8$ & $-15,0$ & $-22,7$ & 8,5 & 10,2 & 19,2 & 18,9 & 24,8 & 4,3 \\
Estonia & 25,3 & 15,6 & 23,4 & 25,4 & 29,4 & 27,2 & 36,2 & 24,2 & 25,8 \\
Hungary & 30,3 & 8,3 & 13,2 & 27,5 & 11,1 & 14,8 & 12,3 & 10,0 & 15,9 \\
Latvia & 33,1 & 46,51 & 33,9 & 33,4 & 38,2 & 53,2 & 48,6 & 21,8 & 38,6 \\
Lithuania & $-4,8$ & 7,8 & 27,2 & 56,4 & 37,3 & 59,4 & 35,4 & 35,1 & 31,7 \\
Poland & 5,8 & 1,9 & 2,4 & 5,8 & 6,1 & 7,1 & 22,7 & 28,5 & 10,0 \\
Romania & $-10,2$ & 31,1 & 23,4 & 53,1 & 27,3 & 36,7 & 45,3 & 54,9 & 32,7 \\
Slovak Rep. & $-7,1$ & $-26,2$ & 10,9 & $-19,8$ & $-0,3$ & 24,9 & 17,6 & 19,2 & 2,4 \\
Slovenia & 8,1 & 9,5 & 5,9 & 9,9 & 20,8 & 21,4 & 23,4 & 28,5 & 15,9 \\
\hline CEECs & & & & & & & & & 20,3 \\
\hline
\end{tabular}

* Credit deflated by the CPI-based inflation

** Average over the 2000-2006 period

Source: IMF, Authors' calculations

\section{Financial Structure, Banking Sector and Credit Growth in the CEECs' economies: Stylized Facts}

The CEECs have started their transition process at the beginning of the 1990's. Since then, the structure of their economies and financial sectors has converged toward European standards. However, despite a considerable progress, the convergence process is far from being completed. For example, when compared with the euro zone the CEECs' banking sector and financial markets remain relatively underdeveloped. Indeed, financial market capitalization or 
financial intermediation remains well below the euro zone level even in the most developed new countries ${ }^{2}$.

Nevertheless it is possible to distinguish several similar features among two areas. For example, the CEECs' financial sectors are dominated by private banks, and credit constitutes the most important source of external financing for firms. Moreover, the factors that stimulated credit growth in the periphery countries (i.e. Greece, Ireland, Portugal and Spain), such as an increase in permanent income or a decrease in lending rates, especially for property-related loans, have continued to play an important role in the case of the CEECs as well ${ }^{3}$. Another feature of the CEECs' banking sector is the predominant presence of foreign, mostly European originated, banking groups (Table 2) attracted by these countries' growth perspectives or investment profitability. Indeed, their market share in total banking assets accounts for almost 100 per cent in some countries.

Looking closely at credit development in transition economies, it is possible to notice important similarities among the CEECs such as a large part of foreign-denominated loans in total credits and a growing role of external sources for credit financing. At the same time, significant differences arise. For example, credit growth to the private sector has been rising at different rates (Figure 1), starting at the end of the 1990's in some countries or only recently in

${ }^{2}$ For example, at the end of 2006 total deposits in per cent of GDP reached almost $48 \%$ in five CECs economies (Hungary, the Czech Republic, Poland, Slovakia and Slovenia), 45\% in the three Southern Eastern economies, which was still far from the euro-zone level: $136.5 \%$. When looking at total banking assets in per cent of GDP, these figures reached $85 \%$ in the CECs-5 and 73.5 in SECs-3, compared to $235.5 \%$ in euro zone.

${ }^{3}$ Rapid credit growth has been mostly supported by demand from the private sector, especially from household. At the end of 2006, total credits to non-banks reached in average 55\% of GDP (119.2\% in euro zone), of which almost $20 \%$ to household (54.1\% in euro zone). Unfortunately, data availability does not allow for bank credit data disaggregation. 
the others. Moreover, in some countries the part of foreign-currency credits is more important than in the others.

Table 2: Banking Sector Survey, 2007

\begin{tabular}{|c|c|c|c|c|c|c|}
\hline \hline & $\begin{array}{c}\text { Number } \\
\text { of Banks }\end{array}$ & $\begin{array}{c}\text { \% of Foreign- } \\
\text { owned Banks }\end{array}$ & $\begin{array}{c}\text { Capital } \\
\text { Adequacy }\end{array}$ & ROA & ROE & $\begin{array}{c}\text { \% of Foreign- } \\
\text { currency Credits in GDP }\end{array}$ \\
\hline Bulgaria & 32 & 80 & 14,5 & 2,2 & 24,4 & 20,6 \\
Croatia & 37 & 90 & 13 & 1,5 & 12 & 13,6 \\
Czech Rep. & 37 & 97 & 11 & 1,2 & 22,4 & 10 \\
Estonia & 6 & 50 & 13 & 1,28 & 21,2 & 78 \\
Hungary & 29 & 81 & 10,8 & 1,9 & 24,7 & 43,6 \\
Latvia & 22 & 40 & 12,3 & 2 & 25 & 78 \\
Lithuania & 13 & 77 & 10,8 & 1,5 & 21,3 & 52,8 \\
Poland & 63 & 67 & 13,2 & 1,8 & 23,0 & 26,6 \\
Romania & 38 & 65 & 17,0 & 1,3 & 10,1 & 12,8 \\
Slovak Rep. & 24 & 99 & 18,7 & 1,1 & 18,7 & 22 \\
Slovenia & 22 & 40 & 11 & 1,3 & 12 & 55,4 \\
\hline \hline
\end{tabular}

* of risk weignted assets

ROA - Return on Assets, ROE - Return on Equity

Source: Raiffeisen Bank Report, the IMF Country Reports

This is particularly visible in the Baltic's countries where the foreign-currency loans reached almost $80 \%$ of GDP (52.8\% in Lithuania), but also in Hungary, where these credits accounted for almost $43.6 \%$. When looking at the other countries, credit growth has visibly accelerated in the Southern European countries (Croatia, Bulgaria and especially in Romania), but also in Slovenia. Credit expansion in the remaining economies, namely Poland and the Czech and Slovak Republics has been less remarkable, but still some visible acceleration could be noticed in the very recent period. 
Figure 1: Changes in Credit to the Private and Public Sector, Domestic Deposits and Banks' Net Foreign Liabilities (1994 -2007) in \% of GDP.

Southern Eastern European Countries
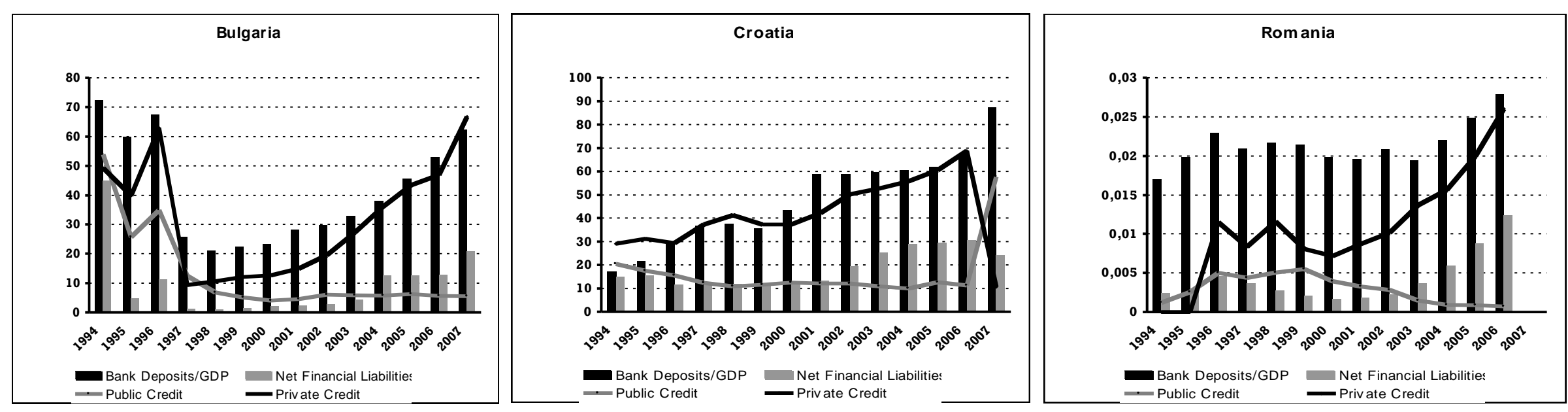

Baltic Countries
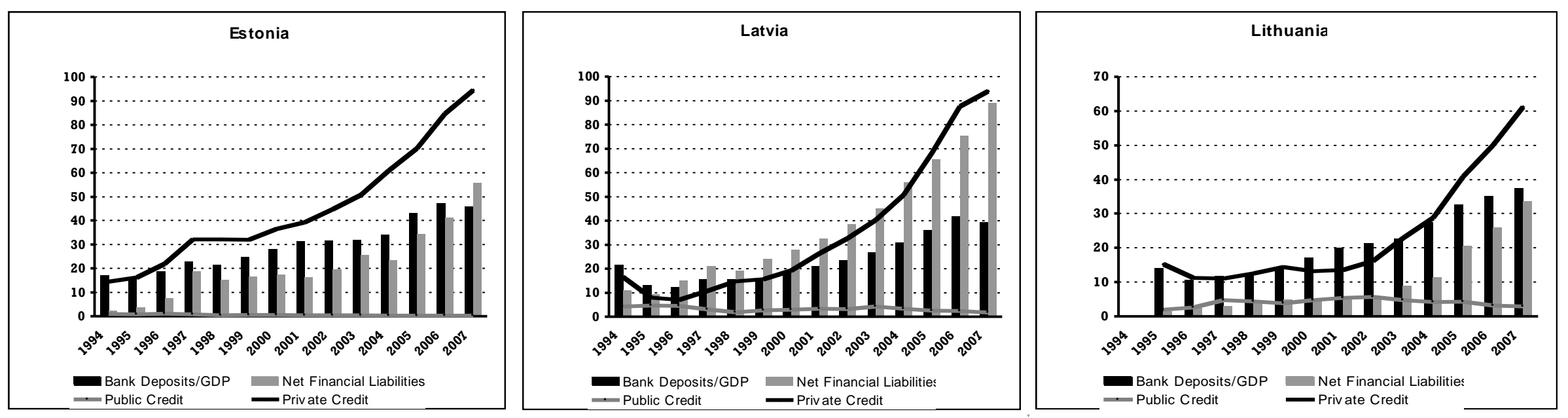
Central Eastern European Countries
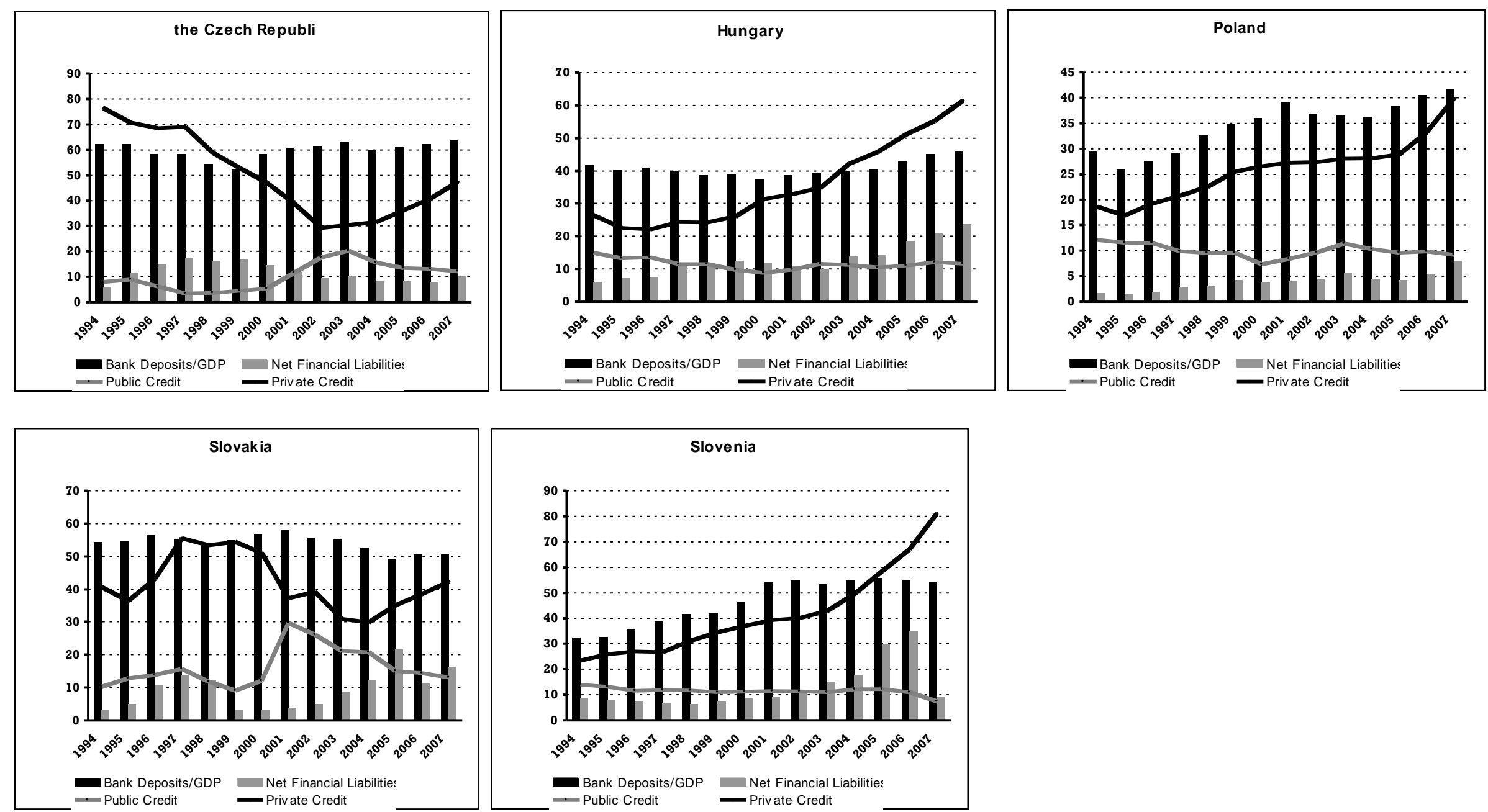

Source: IMF, Authors' calculations 
This heterogeneity in credit dynamics can have various causes, such as a different degree of economic development, development of financial intermediation, and different institutional and regulatory frameworks.

\section{Explanations of "excessive" credit growth}

Credit growth is a particularly difficult subject to deal with mostly because there is not a possible way to quantify a universally accepted threshold value beyond which its increase can be considered as "excessive". To overcome this problem, some authors ${ }^{4}$ try to identify different types of behavior in credit movements, i.e. to distinguish between its normal pattern (trend) and excessive growth.

The "normal" credit behavior makes reference to the theoretical argument of "financial deepening" in developing economies, while "excessive" credit growth is usually explained by the "financial accelerator theory" or behavioral models.

According to the first group of works there exists a positive relationship between financial development and economic growth. Indeed, an efficient financial sector contributes to economic growth ${ }^{5}$. However, the causality between financial development and economic growth can also be the opposite, and the economic development can increase financial intermediation.

\footnotetext{
${ }^{4}$ Other ones try also to set up the so-called speed limit on the basis of previous crises experiences. For example, a credit-to-GDP ratio that exceeds 9.3 per cent can be considered as a leading indicator of banking crisis (Kaminsky and Reinhart, 1996).

5 This argument is supported by partisans of "supply-leading phenomenon" (McKinnon, 1973) and used in some growth models incorporating financial sector (Romer, 1986, 1990; Lucas 1988, Grossman and Helpman, 1991 or Aghion and Howitt, 1992. For more details see for example Levine, 1997.
} 
To be more precise, a rise in a country wealth and income increases demand for financial services contributing to greater credit dynamics ${ }^{6}$.

In contrast, the "financial accelerator theory" and behavioral models explain rapid credit growth by its pro-cyclical nature, deriving from the developments in the real and financial sectors. In the first models, especially in their modern versions, credit expansion results from over-optimism about future earnings that increases collateral value of secured debts and borrowers' credit limits ${ }^{7}$. In the behavioral models, another material source of financial procyclicality is added to explain "excessive" credit growth: mis-measurement of risk in the financial market that is underestimated in booms an overestimated in recessions ${ }^{8}$. Both episodes correspond to "excessive"9 credit expansion that can lead to its "reverse", and endanger financial and/or economic stability.

${ }^{6}$ This causality, based on "demand-following hypothesis", was put forward for example by Gurley and Shaw, 1967, Goldsmith, 1969, or Jung, 1986.

${ }^{7}$ For a synthesis of the leading approaches on the role of credit market frictions in business fluctuations, see a general equilibrium model as developed by Bernanke et al., 1999.

${ }^{8}$ For further explanation of procyclicality of the financial system and financial stability see Borio et al., 2001.

${ }^{9}$ However, two important remarks should be made when one explain "excessive" nature of credit growth in developing countries. First, credit expansion can also correspond to its normal cyclical component when, at the beginning of a cyclical upturn, firms' needs in working capital, i.e. investment funds, increase ("conventional accelerator models", IMF, 2004). Second, except the aforementioned, structural and cyclical, factors of credit growth, it is possible to add more groups of policy and transition-related credit determinants (Arcalean et al., 2007). The first one consists in processes such as deregulation, liberalization and privatization, and finally economic and financial integration that have also concerned the CEECs' economies. The second group includes policy-related factors like the choice of monetary and exchange rate regime or other governmental actions (for example. the crowding-in and crowding-out effects, specific insurance schemes and guarantees). However, empirical studies proved that it is difficult to determine which factors effectively drive credit expansion and, per se, to assess the optimal level of its growth. 
Following aforementioned theoretical frameworks on credit developments, we will say that credit growth becomes "excessive" if it exceeds the level justified by a country financial deepening as determined by its economic development. More precisely, we consider each situation when credit-to-GDP ratio exceeds the "normal" level by certain value as "excessive" credit growth (Figure 2).

\section{Figure 2: Excessive credit growth}

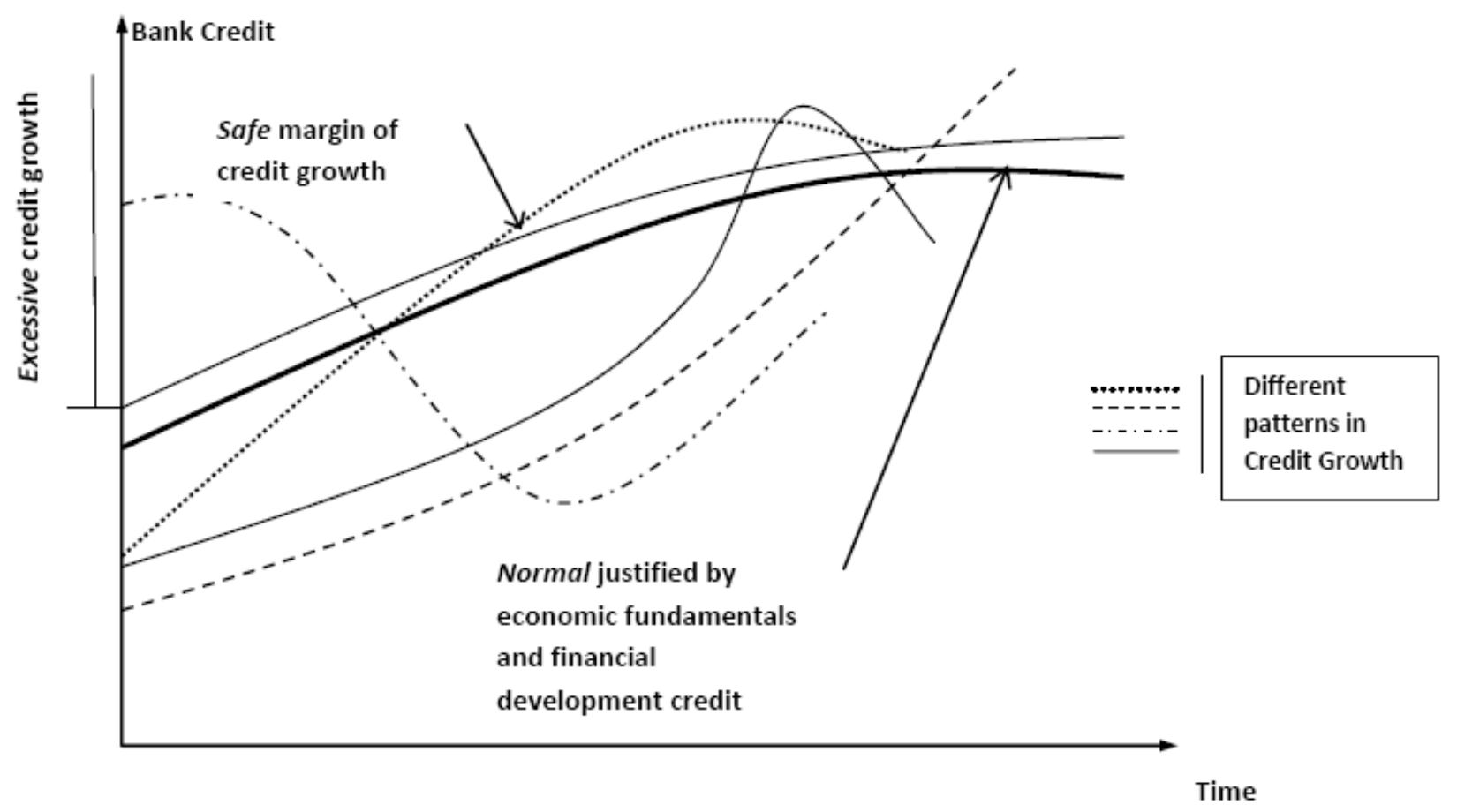

Let's now look at this problem from a more technical point of view.

\section{Methodology}

\subsection{Overview of the Problem}

To determine whether credit growth can be considered as "excessive", it is possible to adopt two different approaches. One way to accomplish this objective is to estimate a country- 
specific trend and compare it with the actual credit development. Another way consists in the estimation of a country's long-run equilibrium as determined by fundamentals of the economy and to compare it with the actual development (behavioral approach). In both cases, the size of deviation between the two values can indicate potential "excessiveness" of credit growth. However, these aforementioned methods present at least three visible limitations:

First of all, it is still rather difficult to determine to which extent credit deviation can be deemed as "sustainable". The usual way consists in comparing the size of deviation to the level of financial development in the country and to the previous leading-to-crises experiences. But, even if authors try to establish the safe size of deviation on these bases, the problem of the threshold choice remains.

The second drawback concerns transition economies' specific bias. Indeed, the short data span and especially the initial low level of banking credit biases the estimation results. So, a common solution is to estimate the long-term equilibrium of credit growth for a benchmark panel of countries that did not present such initial characteristics. These out-of-sample estimates allow determining if credit growth exceeds its equilibrium value.

Finally, despite the visible contributions of these approaches, they cannot be used to determine ex ante the link between credit growth and financial or economic stability.

In this work we try to combine the aforementioned methods (Short Literature Review is included in Table 3) and compare the estimation results with previous findings to obtain the most exact view on credit developments in the new countries.

In the following sections, we present these steps. 


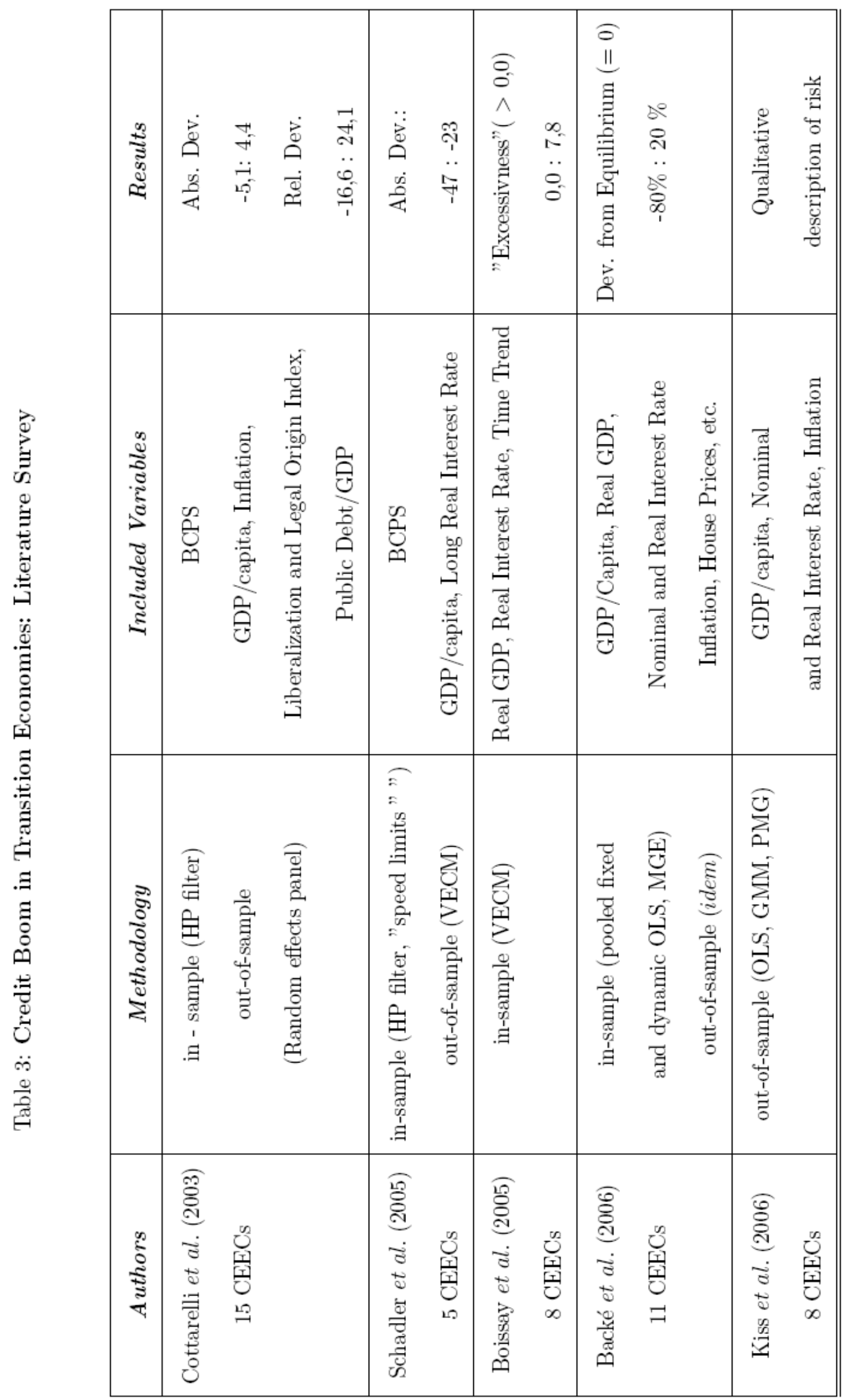




\subsection{Estimating Credit Deviation}

\section{Methods}

As first step, we construct a country-specific backward-looking stochastic trend using the Hodrick-Prescott (HP) filter as proposed by Gourinchas et al. (2001). The HP filter ${ }^{10}$ is applied on the credit-to-GDP ratio recursively from the beginning of the sample to successively the last five year include, i.e. 1995-2002, 1995-2003, ..., 1995-200711. Then the predicted credit ratio is compared to the actual one taking into account the size of each country's banking sector (relative deviation) and financial development (absolute deviation). To determine if the resulting deviations indicate an "excessive" credit increase we employ the threshold values as established in our benchmark study, i.e. 4.8 ("limit threshold") to 6.4 ("boom threshold") per cent for the absolute deviation and 24.9 - 31.1 for the relative one. Finally, we compare the obtained results to the credit deviations in the previous periods.

As a second step, we estimate the long-term relationship between the credit-to-GDP ratio and the different groups of explanatory variables. The baseline specification includes GDP per capita, real interest rate, inflation (threshold), financial liberalization (spread) and crowding-out (credit to public sector) effects:

$$
\frac{B C P S}{G D P}=f\left(G D P \text { per capita, interst rate, inflation, spread, } \frac{B C P P}{G D P}\right)
$$

The estimations are successively carried out for the sample of the CEE and then Western European countries ${ }^{12}$. The variables are pre-tested for the presence of unit roots,

\footnotetext{
10 The smoothness parameter is set at 100 , but the results are qualitatively unchanged if a smoothness parameter of 6 is used.

11 The results are robust to different filtering methods such as band pass and differencing. Additional results are available from the authors upon request.

12 Estimation results are reported in Table 5 - 10 in Appendix B).
} 
applying traditional panel unit tests ${ }^{13}$ that fail to reject the null hypothesis of a unit root in levels and reject the null of a unit root in first differences. However, we do not run the cointegration tests since the error correction terms from the pooled mean group (PMG) estimations can be used for this purpose. Indeed, if the variables are cointergrated the coefficient associated to the error term should have a negative statistically significant $\operatorname{sign}^{14}$. The long-term equilibrium is then estimated using three different specifications.

\section{Model's specifications}

The first specification consists in the traditional static panel model using a fixed-effects estimator. However, since we fear possible endogeneity problem and our concern is about the credit development in the CEECs' economies, we introduce dynamic relationships in the second specification by including lagged dependent variables among the regressors. This dynamic panel model is estimated carried out by the GMM-Arellano and Bond estimator (1991).

The two aforementioned models can already provide useful information about credit developments, but their major limitation is that they estimate the average values of the parameters assuming homogeneity across the sample ${ }^{15}$. So, we also model credit dynamics applying the following pooled mean group (PMG) estimator as developed by Pesaran, Shin and Smith (1999) ${ }^{16:}$

${ }^{13}$ Levin, Lin and Chu (2002), Breitung (2000), Im, Pesaran and Shin (2003), Fisher-type tests. The results are available from the authors upon request.

${ }^{14}$ See Table 6 and 9 in Appendix.

15 Moreover the GMM -Arellano-Bond estimator has been designed for panels with large number of groups $(\mathrm{N})$ relative to number of time series $(\mathrm{T})$ which is not the case in our study.

16 This estimator allows the intercepts, short-run coefficients and errors variances to differ freely, but the long -run coefficients are constrained to be the same across groups. Indeed, there are often good reasons to expect the long -run equilibrium relationships between variables to be similar across groups, due to for example arbitrage condition or common technologies influencing all groups in a similar way. 


$$
\Delta Y_{i t}=\alpha_{i}+\theta_{i}\left(y_{i, t-1}-\beta^{\prime} x_{i, t-1}\right)+\sum_{j=1}^{p-1} \gamma_{i j} \Delta y_{i, t-j}+\sum_{j=1}^{q-1} \gamma_{i j}^{\prime} \Delta x_{i, t-j}+\varepsilon_{i, t}
$$

where, the $\Delta Y_{i t}$ stands for the actual credit-to-GDP ratio, $\beta$ are the common long-run parameters, $x_{i, t-j}$ - is the vector of explanatory variables for group $i$. The country-specific shortterm dynamics are measured by the $\theta_{i}$ parameters (error correction terms) while unexplained country-specific effects are captured by $\alpha_{i}$.

This heterogeneous dynamic model has incontestable advantages in explaining credit growth development in the new countries, since the different countries' features discussed in the previous section imply different dynamics (speed) toward a common long-term equilibrium (Kiss et al., 2006).

\section{In- and out-of-sample estimations}

Since economists in related literature are rather cautious about the appropriateness of insample estimations given the initial bias ${ }^{17}$, we turn to the out-of-sample approach. Indeed, given the aforementioned reasons, the Western European countries seem to constitute a "natural" benchmark for the CEECs' economies, so their long-term parameters can be considered as long-run equilibrium coefficients for the new as well ${ }^{18}$. However, the fact that some variables, even significant, have unexpected signs excludes them from the out-sample

17 Our in-sample estimations seem to confirm these cautions. Indeed, when the initial specification is applied, not all variables seem to be cointegrated, and some long-term coefficients are statistically insignificant and/or have unexpected sings. After testing alternative specifications, for example substituting the credit-to-GDP ratio by real credit growth (Table 8), the results are more robust, but still some important biases, such as the insignificance of the GDP-per-capita ratio, remain.

18 Following previous studies, e.g. Maeso-Fernandez et al. (2006), we use the constant term of the "benchmark" countries in the out-of-sample estimations. This value is obtained from the median value of a range of constants. 
benchmark specification. So, our final specification includes only two variables standard: the GDP per capita and real interest rate.

Indeed, it is rather common to use the GDP per capita ratio as a credit determinant since financial deepening increases with economic development and permanent income. The role of the real interest rate as the cost of borrowing is also straightforward (see Appendix A for the further explanations).

The estimated long-term coefficients are then applied to compute the equilibrium level of credit for each CEEC and to calculate the deviation between actual and predicted credit values. Finally, we compare the obtained results with the previous findings.

\section{Data Issues}

Our estimations are carried out for annual data provided by the IMF and World Bank databases and cover the 1994-2007 period for the CEECs and the 1980-2003 period for the Western European countries. The CEEC countries include: Bulgaria, Croatia, the Czech Republic, Estonia, Latvia, Lithuania, Poland, Romania, the Slovak Republic and Slovenia. The Western European countries include: Belgium, Denmark, Finland, France, Germany, Ireland, Italy, The Netherlands, Portugal, Spain, Sweden and the United Kingdom ${ }^{19}$.

\section{Results}

\section{Credit Deviation from Trend}

Table 4 reports the credit-to-GDP ratio and its absolute and relative deviations from the trend. In 2007, seven of the studied countries, i.e. Bulgaria, the Czech Republic, Estonia, Latvia Lithuania, Romania and Slovenia had credit growth in absolute terms well above the upper

\footnotetext{
19 We are unfortunately obliged to exclude some countries from the estimations due to data availability problems. Luxemburg is traditionally excluded from this kind of study due to the size of its financial sector
} 
bound ("boom") of the threshold range and one of them (Slovakia) experienced an absolute deviation close to the upper bound of the threshold band. These findings constitute a significant change when compared with previous credit developments. Indeed, in 2002, only one country, Latvia, had an increase in the credit-to-GDP ratio that could be classified as "excessive", i.e. superior to the lower bound of the threshold range. In 2004, credit growth in Bulgaria pushed this country over the "credit boom" limit and three countries (Estonia, the Czech Republic and Lithuania) remained between the threshold limits. In 2006, three more countries (Croatia, Romania and Slovakia) experienced "excessive" credit growth exceeding lower bound of the threshold range.

When comparing credit development to the size of banking sector, only Bulgaria, the Czech Republic and Romania had a relative deviation superior or close to the upper bound of the "safe" threshold since at least 2003.

However, a closer examination of the results reveals that the credit increase is particularly important in almost all of the countries under consideration, even if this evolution is less visible in Croatia and Hungary when this method is applied. Poland constitutes a rather interesting case. Indeed, this country credit dynamics has visibly accelerated only in 2007; until then credit growth remained relatively safe (e.g. absolute and relative deviations in 2006 were respectively 1.5 and 4.5\%). It seems indeed that Poland of all CEECs' has experienced the shorter during one-year credit boom. 


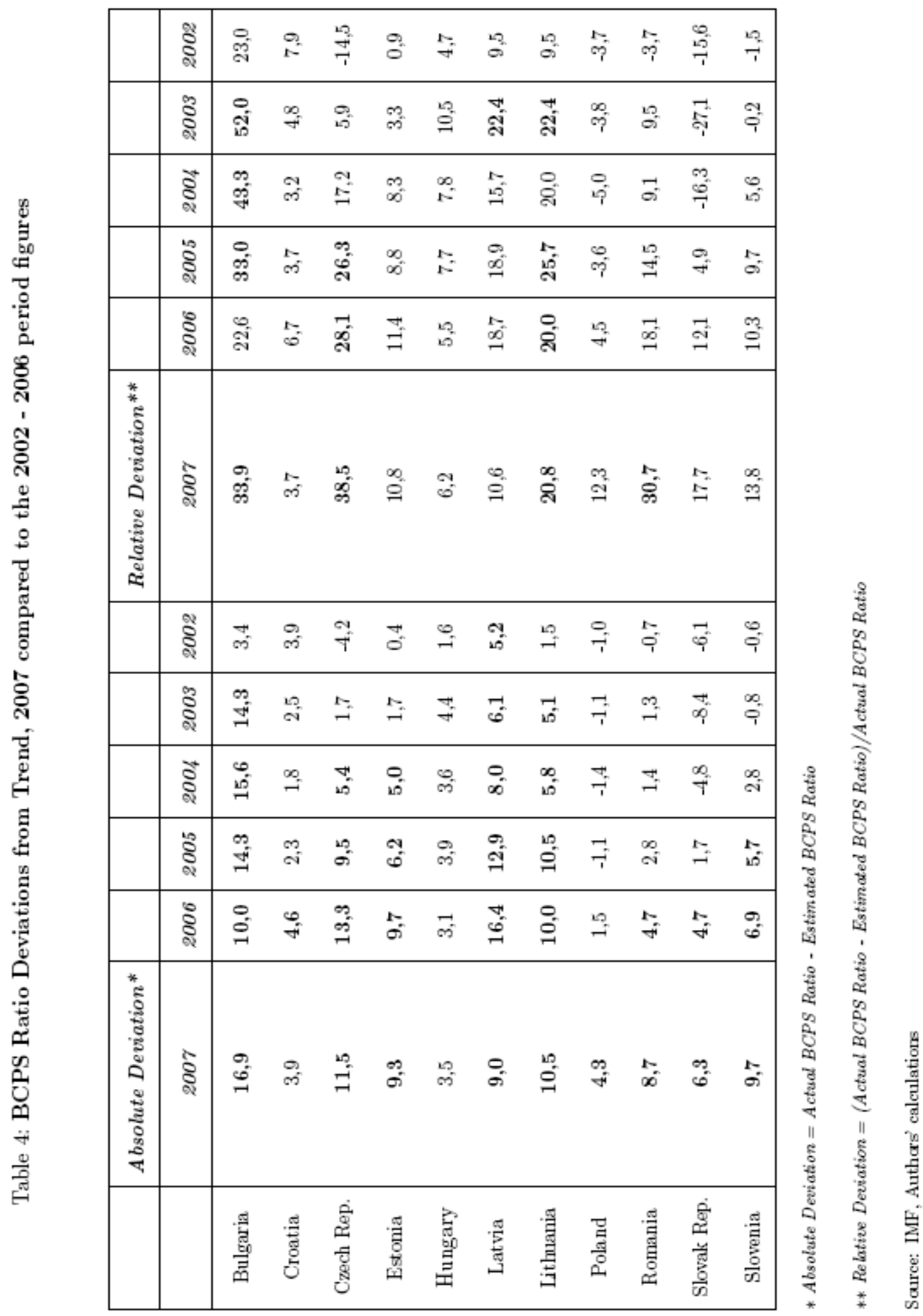




\section{Credit Deviation from long-term equilibrium}

When we look at the out-of-sample estimations ${ }^{20}$ of credit growth, the results included in Figure 3 seem to corroborate most of our previous findings. Indeed, the recent credit development has "pushed" the CEECs' credit-to-GDP ratio closer or even beyond its long-term fundamental equilibrium, confirming the thesis about "excessive" credit growth in the region.

More precisely, the countries that suffered from the credit contraction in the 1990's seem to improve their credit dynamics. The credit equilibrium has been achieved and even exceeded recently for Bulgaria, Hungary and Lithuania. In the Czech and Slovak Republics, the creditto-GDP ratio showed a positive turning point in 2004. However, this tendency was much slower for Poland and Romania, where credit dynamics have been relatively stable ${ }^{21}$.

For the last group of countries, Croatia, Estonia, Latvia, and recently Slovenia, our findings confirm what some economists have anticipated for some time, namely the persisting "overshooting" in credit development. Indeed, these countries' credit-to-GDP ratio has stayed well beyond their long-term equilibrium for at least the three or four last years. In the case of Croatia and Latvia, however, some deceleration in credit growth can already be noticed since 2006

So, when considering both estimation methods, we can depict visible "excessive" credit boom since at least 2005/2006 for almost all countries. In some of them "credit boom" has started earlier in $2003 / 2004$, but all countries experienced peaks in credit expansion during the last three years.

${ }^{20}$ For the aforementioned reasons, the long-term coefficients as estimated by the PMG estimator were used for this purpose.

${ }^{21}$ It is worth to underline that in the case of these two countries credit growth did accelerate in the recent period, but this tendency has also concerned the GDP per capita evolution, a variable used to determine the credit long-term equilibrium in our study. 
Figure 3 : Credit Deviation in the CEECs (out-of-sample estimations)

\section{The Southern Estaern European Countries}

Bulgaria

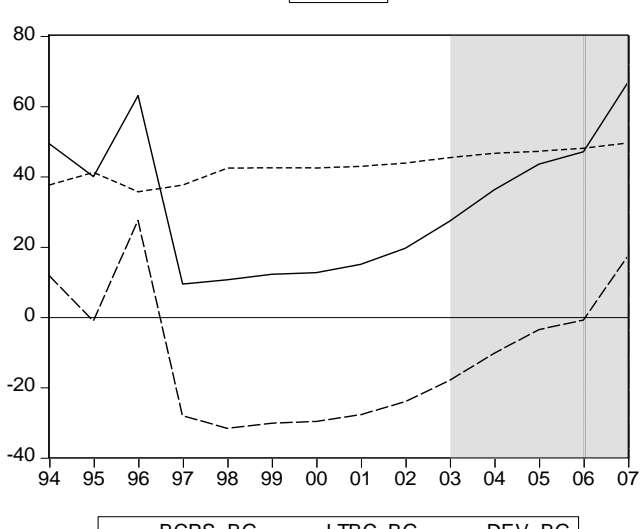

- BCPS_BG -----LTBC_BG --- DEV_BG

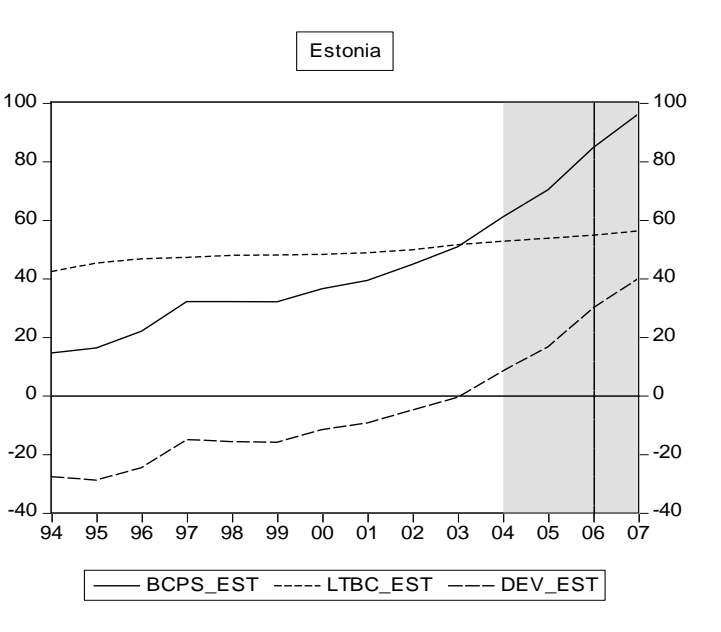

Croatia

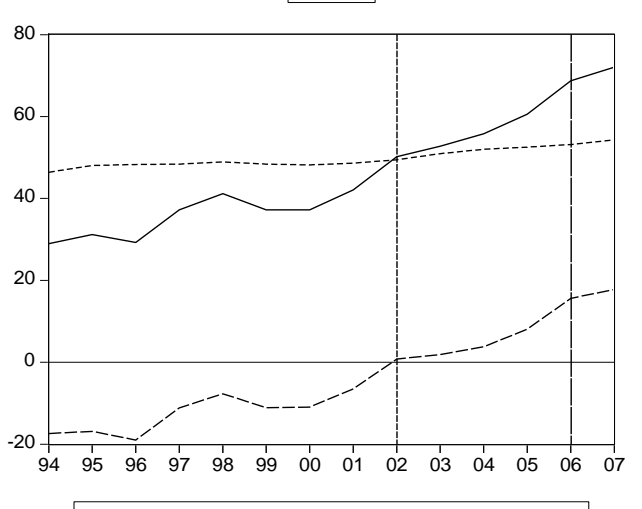

The Baltics Counries

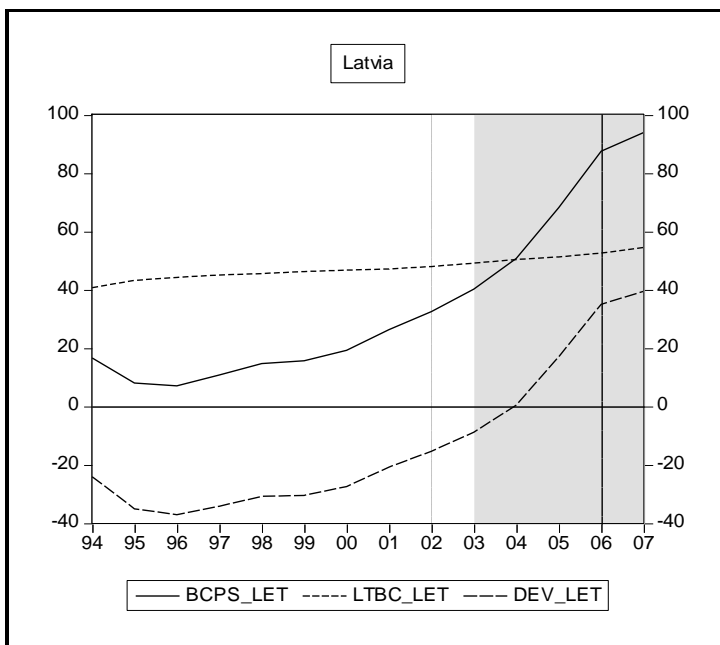

Romania

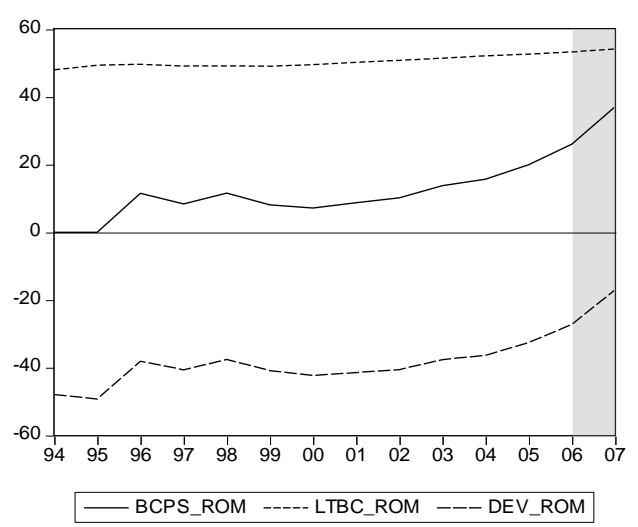

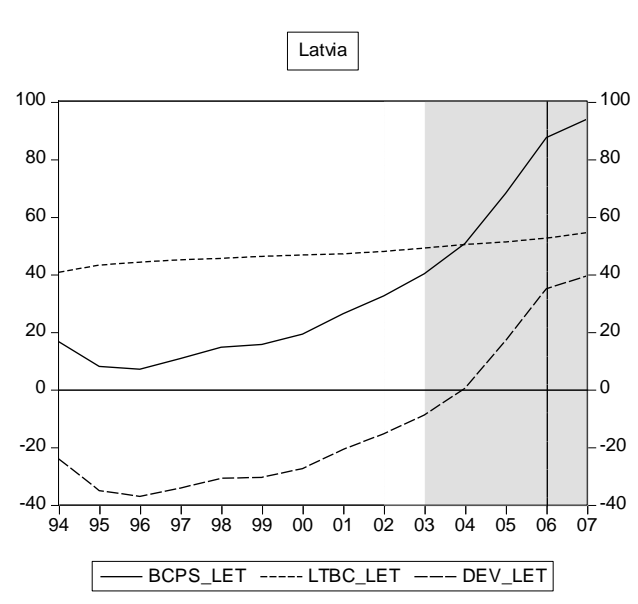


The Central Eastern European Countries
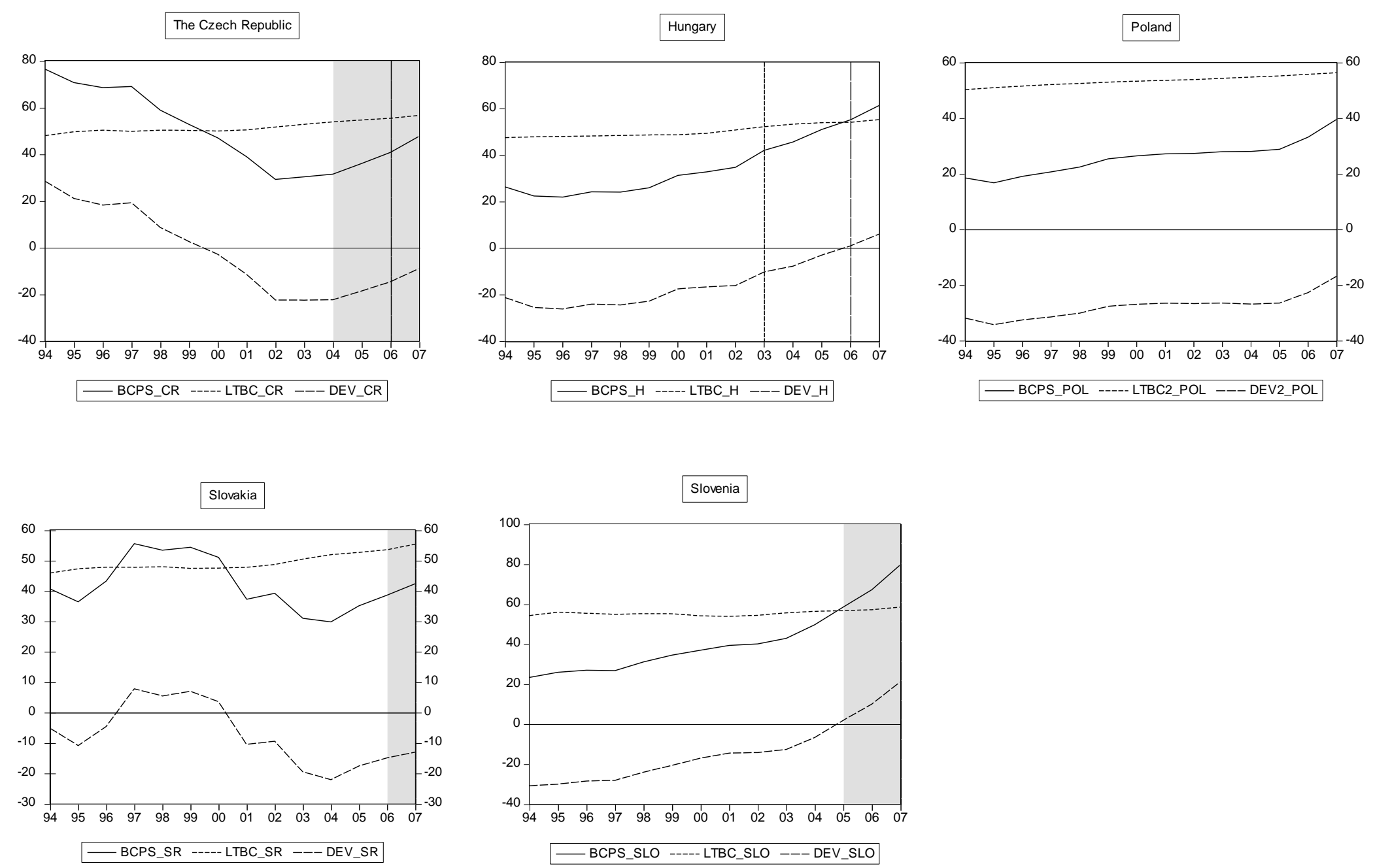

Source: Author's estimations 


\section{Conclusion}

In this work, we attempted to investigate whether the recent bank credit growth in 11 Central and Eastern European countries can be considered as "excessive", i.e. "unsustainable", for their financial and macroeconomic stability. Since it is relatively difficult to quantify the "excessiveness" of credit development and even more to determine with certitude whether the "excessive" credit growth can lead to financial crises, the literature on the subject has been rather limited. We tried however to regroup few existing methodological approaches and focus more on the first part of the problem. This is why credit growth was viewed as "excessive" when it exceeded the equilibrium value that could be justified by country's financial development and economic fundamentals. The critical values were determined at the basis of a stochastic trend and panel estimations of the long-term equilibrium. The first method was carried out using the Hodrick-Prescott filter, and the second one applied the fixed-effects, dynamic and pooled mean group estimators.

Our estimation results reported the "excessive" or close to "excessive" credit growth in the case of at least eight studied countries (Bulgaria, Croatia, Estonia, Latvia, Lithuania, Hungary, Romania and Slovenia) at the end of the studied period. However, a general peak in credit expansion that can be qualified as "excessive" can be noticed since the last three years in all countries under consideration. This "excessive" credit growth could probably end in the nocrisis-driving "soft landing", as is usually the case in "credit boom" episodes, but under the actual financial turmoil circumstances and general economic slowdown, this development has reinforced the CEECs' financial and economic vulnerabilities. Indeed, a group of countries has already noted the negative turn in capital movements at the end of the last year that could lead, without common coordinated action of international institutions and national governments, to banking and financial crises, and in almost all CEECs' economies "expensive adjustment" (Natixis, 2009) is still to come. 


\section{References}

Andersen C., 2009, "IMF Helping Counter Crisis Fallout in Emerging Europe", IMF Survey online.

Arcalean C., O. Calvo-Gonzalez, C.More, A. van Rixtel, A.Winkler and T.Zumer, 2007, "The Causes and Nature of the Rapid Credit Growth of Bank Credit in the Central, Eastern and South-eastern European Countries" in Enoch Ch., Ötker-Robe I.(dir.) "Rapid Credit Growth in Central and Eastern Europe: Endless Boom or Early Warning?”, Palgrave Macmillan eds.

Backé P., B.Egert and T. Zumer, 2006, "Credit Growth in Central and Eastern Europe. New(Over)shooting Starts ?", ECB Working Paper Series no 687.

Baltagi B.H., 2008, "Econometric Analysis of Panel Data”, John Wiley and Sons Ltd. Eds.

Bernanke B., M.Gertler and S.Gilchrist, 1999, “The Financial Accelerator in a Quantitative Business Cycle Framework" in Handbook of Macroeconomics, volume 1C, Handbook in Economics, volume 15, Elsevier.

Boissay F., O.Calvo-Gonzalez and T.Kozluk, 2006, "Is Lending in Central and Eastern Europe Developing too Fast?" in Enoch Ch., Ötker-Robe I.(dir.), "Rapid Credit Growth in Central and Eastern Europe: Endless Boom or Early Warning?”, Palgrave Macmillan eds.

Borio C., C. Furfine and P. Lowe, 2001, "Procyclicality of the financial system and financial stability: issues and policy options", BIS Papers 1a,

Brzoza-Brzezina M., 2005, "Lending booms in Europe's periphery: South-Western Lessons for Central -Eastern members”, ECB Working Paper 543.

Caldéron C. and L. Liu, 2002, "The direction of causality between financial development and economic growth", Central Bank of Chile, Working Paper no. 184/2002. 
Cottarelli C., G. Dell'Ariccia and I. Vladkova-Hollar , 2003, "Early Birds, Late Risers, and Sleeping Beauties: Bank Credit Growth to the Private Sector in Central and Eastern Europe and the Balkans”, IMF Working Paper WP/03/213.

Coudert V., C. Pouvelle, 2008, "La croissance des crédits dans les pays d'Europe central et orientale est-elle excessive? ”, Bulletin de la Banque de France, n¹72, Avril 2008.

Enoch Ch., Ötker-Robe I.(dir.), 2007, "Rapid Credit Growth in Central and Eastern Europe: Endless Boom or Early Warning?", Palgrave Macmillan eds.

Ghosh A.R. Gulde A.-M., Wolf H.C., 2002, "Exchange Rate Regimes. Choices and Consequences”, Business \& Economics.

Gourinchas P.-O., R.Valdés and O.Landerretche, 2001, "Lending Booms: Latin America and the World”, NBER Working Paper Series no 8249.

Hilbers P., I. Ötker-Robe and C. Pazarbasioglu, 2007, "Analysis of and Policy Responses to Rapid Credit Growth" in in Enoch Ch., Ötker-Robe I.(dir.), "Rapid Credit Growth in Central and Eastern Europe: Endless Boom or Early Warning?", Palgrave Macmillan eds.

IMF, 2004, “Are Credit Booms in Emerging Markets a Concern?”.

IMF Country Report No.07/256

IMF Country Report No.08/247

IMF Country Report No.09/3

Kiss G., M. Nagy and B. Vonnak, 2006 "Credit Growth in Central and Eastern Europe: Trend, Cycle or Boom”, MNB Working Paper 2006/10.

Levine R., 1997, "Financial Development and Economic Growth: Causality and Causes", Journal of Monetary Economics 46, 
Natixis, 2009, "Europe centrale et orientale", Janvier 2009.

Pesaran M.H., Y. Shin and R.P. Smith, 2003, "Pooled Mean Group Estimation of Dynamic Heterogeneous Panels", Occasional Paper No. 3/2002, University of Ljubljana, Institute of Economic Research.

Raiffeisen Bank Research, 2008, “CEE Banking Sector Report 2008”, www.raiffeisenbank.ba/en/vijesti/2008/02102008.htm

Reinhart C.M., 2002, "Sovereign Credit Ratings Before and After Financial Crises", MPRA Paper 7410, University Library of Munich, Germany.

Schadler S., Drummond P., Kuijs L., Murgasova Z., van Elkan R., 2005, “Adopting the Euro in Central Europe: Challenges of the next Step in European Integration”, IMF Occasional Paper, 234.

\section{Appendix A}

\section{Variables description:}

The Credit-to-GDP ratio. It is rather common in the case of the CEECs' economies to model the equilibrium credit-to-GDP ratio instead of credit itself (Boissay et al., 2006) since the evolution of this ratio can be considered as the progress in their transition process.

The log of GDP per capita. A positive relation between two variables is expected since financial deepening increases with economic development and permanent income and viceversa.

Real Interest Rate. Interest Rate is adjusted by current inflation rate to capture the cost of borrowing. 
Inflation threshold. High inflation, i.e. exceeding certain threshold value, is excepted to have negative effect on credit growth. The non-linear threshold is set as in Cottarelli et al. (2003) and Khan et al. (2001) at 4 per cent and inflation dummy is computed as follows: inf $=$ dum $\times$ CPI .

Financial Liberalization Effect. Several authors establish a positive effect that financial liberalization has on financial deeping. This effect is approximated by a decreasing spread between lending and deposit rates.

Crowding-in, Crowding-out effect. A negative relation between an increase in bank credit to the public sector and financial development is rather straightforward.

\section{Appendix B}

\section{Estimation results:}

Table 5: Long-term relationships between the credit-to-GDP ratio and explanatory variables: Panel Regressions, CEECs

\begin{tabular}{|c|c|c|c|c|c|}
\hline Coefficients & GDP/cap & Int.Rate & Inf. & Credit Public Sector & Spread \\
\hline Fixed Effects Estimator & $0.18^{* * *}$ & $1.43^{*}$ & $-5.16^{*}$ & $-0.81^{* *}$ & $-0.29^{* * *}$ \\
Dynamic Estimator & $0,03^{* * *}$ & $-1.84^{* * *}$ & $-8.47^{* * *}$ & $-0.21^{* * *}$ & $-0.28^{* * *}$ \\
PMG Estimator ${ }^{1}$ & $-1.03^{*}$ & $-0.21^{* * *}$ & $-3.27^{* * *}$ & $-0.02^{* * *}$ & $-0.05^{* * *}$ \\
\hline
\end{tabular}

$* /{ }^{* *} /{ }^{* *}$ significant respectively at the $10 \%, 5 \%$ and $1 \%$

${ }^{1}$ Real GDP was used instead of the BCPS ratio, see page 12 for the further explanation. 
Table 6: Error Correction Terms $\left(\theta_{t}\right)$ from the PMG estimator: CEECs

\begin{tabular}{|c|c|}
\hline Bulgaria & $-1.00^{* *}$ \\
Croatia & $-1.29^{* * *}$ \\
Czech Rep. & -0.52 \\
Estonia & $-1.33^{* * *}$ \\
Hungary & $-0.87^{* * *}$ \\
Latvia & $-1.30^{* * *}$ \\
Lithuania & $-0.61^{* *}$ \\
Poland & $-1.50^{* * *}$ \\
Romania & $-1.15^{* * *}$ \\
Slovak Rep. & $-1.03^{* * *}$ \\
Slovenia & $-1.16^{* * *}$ \\
\hline
\end{tabular}

$* / * * * * *$ significant respectively at the $10 \%, 5 \%$ and $1 \%$

Source: Author's estimations

Table 7: Long-term relationships between the credit-to-GDP ratio and explanatory variables: Panel Regressions, Western European countries

\begin{tabular}{|c|c|c|c|c|c|}
\hline Coefficients & GDP/cap & Int.Rate & Inf. & Credit Public Sector & Spread \\
\hline Fixed Effects Estimator & $0.742^{*}$ & $-0.058^{* * *}$ & $-0.48^{* *}$ & $-1.888^{*}$ & $1.44^{*}$ \\
Dynamic Estimator & $0.668^{*}$ & $-1.198^{*}$ & $-1.378^{*}$ & $-1.267^{*}$ & $2.043^{*}$ \\
PMG Estimator & 0.036 & $-4.642^{*}$ & $1.226^{*}$ & $-1.486^{*}$ & $1.318^{*}$ \\
\hline
\end{tabular}

$* * * / * *$ significant respectively at the $10 \%, 5 \%$ and $1 \%$

Source: Author's estimations 
Table 8: Long-term relationships between the credit-to-GDP ratio and explanatory variables: Final specification $(B C P S=f(G D P / c a p i t a$, Real Interest Rate $)$ for Western European countries

\begin{tabular}{|c|c|c|}
\hline Coefficients & GDP/cap & Real Interest Rate \\
\hline Fixed Effects Estimator & $0.76^{* * *}$ & $-0.06^{* * *}$ \\
Dynamic Estimator & $0.67^{* * *}$ & $-1.2^{* * *}$ \\
PMG Estimator & $0.60^{* * *}$ & $-1.95^{* * *}$ \\
\hline
\end{tabular}

$* / * * / * * *$ significant respectively at the $10 \%, 5 \%$ and $1 \%$

Source: Authors' estimations

Source: Author's estimations

Table 9: Error Correction Terms $\left(\theta_{t}\right)$ from the PMG estimator: Final Specification

$(B C P S=f(G D P / c a p i t a$, Real Interest Rate $)$ for Western European countries

\begin{tabular}{|c|c|}
\hline \hline Belgium & $-0.280^{* *}$ \\
Denmark & $-0.621^{* * *}$ \\
Finland & $-0.077^{* * *}$ \\
France & $-0.449^{* *}$ \\
Germany & $-0.095^{* *}$ \\
Ireland & $-0.632^{* * *}$ \\
Italy & $-0.391^{* * *}$ \\
The Netherlands & $-0.384^{* * *}$ \\
Portugal & $-0.109^{* *}$ \\
Spain & $-0.258^{* *}$ \\
Sweeden & $-0.806^{* * * *}$ \\
The United Kingtom & $-0.124^{* * *}$ \\
\hline \hline
\end{tabular}

$* /{ }^{* *} / * *$ significant respectively at the $10 \%, 5 \%$ and $1 \%$

Source: Author's estimations 